\title{
Pregnancy and SARS - CoV - 2 vaccination: Unraveling the myths
}

\author{
Anita Yadav, Jyoti Baghel, Avinash Prakash, Rajneesh Rawat
}

\begin{abstract}
Corresponding author: Dr Jyoti Baghel, Senior Resident, Department of Obstetrics \& Gynecology, All India Institute of Medical Sciences, Nagpur, Plot No. 2, Sector - 20, MIHAN, Nagpur, Pin: 441108, India; Email : bagheljyoti@aiimsnagpur.edu.in
\end{abstract}

Distributed under Attribution-Non Commercial - Share Alike 4.0 International (CC BY-NC-SA 4.0)

\begin{abstract}
The development and implementation of SARS- CoV- 2 vaccination programs seem to be the main weapon for tiding over the ongoing pandemic. Despite pregnant women being a vulnerable group, they have been excluded from the ongoing vaccination drive in India. Amidst the second wave of SARS- CoV- 2, vaccination should be extended to pregnant women too. This manuscript highlights various aspects of the available vaccines for pregnant women. It also depicts the need for counseling in pregnant women regarding the direct and indirect advantages of vaccination, while acknowledging the paucity of safety data. Thus, vaccines should not be withheld from pregnant women who make an informed choice.
\end{abstract}

Keywords: Covid-19, vaccination, pregnancy, concerns.

The world has witnessed the devastating effects of the deadly severe acute respiratory syndrome coronavirus 2 (SARS- CoV- 2) pandemic. It has led to unprecedented public health challenges, disrupting the economies, and has resulted in a mental health crisis. According to world health organisation (WHO) globally, there have been 170,812,850 confirmed cases of COVID-19, including 1,581,509,628 deaths (2 June 2021) ${ }^{1}$. In the absence of definitive treatment for COVID- 19, measures like social distancing, face masks and personal hygiene are useful but maintaining these actions is not feasible in the long term. Thus, herd immunity by vaccination becomes the most effective eradication method, as evident in the past epidemics.

The development of a vaccine for SARS- CoV- 2 was urgently needed for controlling the ongoing pandemic. As soon as the virus was identified, various nations including India accelerated their efforts for developing an effective vaccine. On $3^{\text {rd }}$ January, the drug controller general of India (DCGI) approved Covishield (by the serum institute of India) and Covaxin (by bharat biotech) for restricted use against covid-19. India's much-awaited immunization program began on 16 january 2021 in a phased manner. In april 2021, the Russian Sputnik V vaccine (distributed locally by Dr. Reddy's laboratories) got approval as a third vaccine. Various types of SARS- CoV- 2 vaccines available worldwide are summarized in table 1 .

Pregnant women are at increased risk of severe disease, intensive care unit admission, and mechanical ventilation when compared with non-pregnant patients of the same age ${ }^{3}$. Pregnant women with pre-existing medical conditions e.g. diabetes, cystic fibrosis, severe asthma, homozygous sickle cell disease, chronic kidney disease and congenital or acquired heart disease further increases the risk of severe Covid 19 illness. At present, most of the studies on the safety

Received: $3^{\text {th }}$ June 2021, Peer review completed: $5^{\text {th }}$ July 2021, Accepted: $7^{\text {th }}$ July 2021.

Yadav A, Baghel J, Prakash A, Rawat R. Pregnancy and SARS - CoV - 2 vaccination: Unraveling the myths. The New Indian Journal of OBGYN. 2021; 8(1): 3-6. 


\begin{tabular}{|c|c|c|c|}
\hline Type of vaccine & Examples & Advantages & Limitations \\
\hline $\begin{array}{l}\text { Whole virus } \\
\text { vaccine (killed) }\end{array}$ & $\begin{array}{l}\text { - } \quad \text { Covaxin } \\
\text { - } \quad \text { Sinovac }\end{array}$ & $\begin{array}{l}\text { Well established technology } \\
\text { Manufacturing process is relatively } \\
\text { simple. }\end{array}$ & Needs booster. \\
\hline $\begin{array}{l}\text { Whole virus vaccine } \\
\text { (live attenuated) }\end{array}$ & $\begin{array}{c}\text { - } \mathrm{A} 50-18 \\
\text { (Not marketed) }\end{array}$ & $\begin{array}{l}\text { Potentially more robust immune } \\
\text { response than killed virus. } \\
\text { May not need a booster dose. }\end{array}$ & $\begin{array}{l}\text { Not suitable for immunecompromised } \\
\text { individuals. }\end{array}$ \\
\hline $\begin{array}{l}\text { Protein subunit } \\
\text { vaccine }\end{array}$ & - $\quad$ Novavax & $\begin{array}{l}\text { No risk of disease transmission as only } \\
\text { a protein is used. }\end{array}$ & $\begin{array}{l}\text { Identifying the particular protein is a long } \\
\text { process. } \\
\text { Booster shots are necessary. }\end{array}$ \\
\hline Viral vector vaccine & $\begin{array}{ll}\text { - } & \text { Covishield } \\
\text { - } & \text { Sputnik V } \\
\text { - } & \text { Jansen } \\
\text { - } & \text { CanSino } \\
& \text { Biologics }\end{array}$ & & $\begin{array}{l}\text { Complex to manufacture. } \\
\text { Requires booster. } \\
\text { Adenovirus transmission to the fetus in a } \\
\text { pregnant woman can occur. This poses a } \\
\text { purely theoretical risk as pathogenicity is } \\
\text { negligible. }\end{array}$ \\
\hline $\begin{array}{l}\text { Nucleic acid } \\
\text { vaccine }\end{array}$ & $\begin{array}{ll}\text { - } & \text { Pfizer } \\
\text { - } & \text { BioNTech } \\
\text { - } & \text { Moderna }\end{array}$ & $\begin{array}{l}\text { Cannot trigger disease process. } \\
\text { Maximum data in pregnancy is related } \\
\text { to these vaccines. }\end{array}$ & $\begin{array}{l}\text { Completely new approach to vaccine } \\
\text { development. } \\
\text { Requires ultra cold chain for transport }\end{array}$ \\
\hline
\end{tabular}

\begin{tabular}{|c|c|}
\hline Name of the body & Recommendations \\
\hline World Health Organization (WHO) ${ }^{7}$ & $\begin{array}{l}\text { - WHO recommends vaccination in pregnant women when the benefits of } \\
\text { vaccination to the pregnant woman outweigh the potential risks. For example- } \\
\text { pregnant women at high risk of exposure to COVID-19 and pregnant women with } \\
\text { comorbidities. } \\
\text { - It is not necessary to conduct pregnancy testing prior to vaccination; nor is there a } \\
\text { need to delay or terminate pregnancy because of vaccination. }\end{array}$ \\
\hline $\begin{array}{l}\text { International Federation Gynecology and } \\
\text { Obstetrics (FIGO) }\end{array}$ & $\begin{array}{l}\text { - There are no risks - actual or theoretical - that would outweigh the potential } \\
\text { benefits of vaccination for pregnant women. } \\
\text { FIGO support offering COVID-19 vaccination to pregnant and breastfeeding } \\
\text { women. }\end{array}$ \\
\hline $\begin{array}{l}\text { Federation of Obstetric and } \\
\text { Gynaecological Societies of India } \\
\text { (FOGSI) }^{2}\end{array}$ & $\begin{array}{l}\text { - Based on the mechanism of the available COVID vaccines; there is no obvious } \\
\text { basis for excluding pregnant or lactating women from vaccination. } \\
\text { It is emphasized that individual practitioners cannot advice vaccination to pregnant } \\
\text { and lactating women in India until there is a change in recommendations from the } \\
\text { MOHFW, GOI. }\end{array}$ \\
\hline $\begin{array}{l}\text { Society of Obstetricians and } \\
\text { Gynaecologists of Canada ( SOGC) }\end{array}$ & $\begin{array}{l}\text { - Pregnant individuals should be offered vaccination at any time during pregnancy or } \\
\text { while breastfeeding if no contraindications exist. } \\
\text { The SOGC supports the use of all available COVID-19 vaccines approved in } \\
\text { Canada in any trimester of pregnancy and during breastfeeding in accordance with } \\
\text { regional eligibility. } \\
\text { Given that pregnant people are at increased risk of morbidity from COVID-19 } \\
\text { infection, all pregnant persons should be eligible to receive a COVID-19 } \\
\text { vaccination. }\end{array}$ \\
\hline $\begin{array}{l}\text { American College of Obstetrics and } \\
\text { Gynaecologists }(\text { ACOG })^{10}\end{array}$ & $\begin{array}{l}\text { - ACOG recommends that pregnant individuals should have access to COVID-19 } \\
\text { vaccines. } \\
\text { COVID-19 vaccines should be offered to lactating individuals similar to non - } \\
\text { lactating individuals. }\end{array}$ \\
\hline
\end{tabular}


and efficacy of vaccines have excluded pregnant women. This has further compounded concerns around safety in this special group. While the available guidelines do not recommend routine vaccination of all pregnant women due to the lack of safety data, vaccinating women with a high risk of occupational exposure to the virus or with preexisting comorbidities could be considered on an individualized basis ${ }^{4}$. For a vaccine to be successful, apart from its efficacy, it has to be accepted by the target population. Despite several studies on vaccine willingness in the general population, pregnant women's perceptions remain unknown ${ }^{5}$.

The main concerns of these vulnerable groups were related to vaccine-specific safety and efficacy. Most of the women had concerns about its effect on fertility. It was claimed that the antibodies recognizing the SARS- CoV-2 spike protein damages the placenta. However, Kloc et al found out that it is unlikely that any spike protein-specific SARS-CoV-2 vaccine would affect fertility and pregnancy ${ }^{6}$. Another concern was the effect of the vaccine on organogenesis. Since the integration of exogenous RNA into the host genome by endogenous reverse transcriptase originating in the placenta cannot be ruled out; hence it is recommended that vaccination be avoided during the period of organogenesis. The recommendations by various international as well as national statutory bodies regarding vaccination in pregnant and lactating mothers are summarized in table 2 .

\section{Conclusion}

At present, in India, pregnant women are excluded from the benefits of ongoing SARS- CoV- 2 vaccine rollout. Considering the current situation, it is advocated that Covid 19 vaccination should not be withheld for pregnant women. They should be counseled regarding the benefits along with the uncertainties and potential harms of the available vaccines. Further research is needed to address the current issues related to SARS- CoV- 2 vaccination in pregnancy.

\section{Key messages}

- Considering the current situation of the pandemic, we advocate that pregnant women should not be excluded from vaccination.

- Before vaccination, pregnant women should be fully informed that the long-term adverse reactions are unknown and that the safety of the vaccine for the fetus and the child is not yet established.

- Vaccination should be avoided during organogenesis (up to 12 weeks of pregnancy)
- Vaccination should be performed at an obstetrics and gynaecology facility to check fetal heart movement before and after administration.

- Vaccination is recommended for pregnant healthcare workers who are at high risk of infection and those with comorbidities, such as obesity and diabetes, may be at risk of severe disease.

The decision of pregnant women and lactating mothers who decline for vaccination should be respected and supported. They should be counseled and empowered to make their own decision supported by the doctors.

Conflict of interest: None. Disclaimer: Nil.

\section{References}

1. World Health Organisation: corona virus disease dashboard. 2021. [Accessed: June 2, 2021]. Available from: https://covid19.who.int/table

2. The Federation of Obstetrics \& Gynecological Societies of India (FOGSI). Fogsi Position Statement Covid Vaccination For Pregnant - Breastfeeding Women. [Accessed on April 29, 2021]. 2021. Available from: https://www.fogsi.org/wp-content/uploads/covid19/fogsi -statement-on-covid-vaccination-in-pregnancy-andbf.pdf

3. Royal College of Obstetricians and Gynaecologists (RCOG) and The Royal College of Midwives. Coronavirus (COVID-19) in Pregnancy Version 13. London: RCOG; 2021.

4. Centers for Disease Control and Prevention. Vaccination considerations for people who are pregnant or breastfeeding. [Accessed on 16 January 2021]. 2021. Available from: https://www.cdc.gov/coronavirus/2019ncov/vaccines/recommendations/pregnancy.html

5. Fisher KA, Bloomstone SJ, Walder J, Crawford S, Fouayzi H, Mazor KM. Attitudes toward a potential SARS-CoV-2 vaccine: A survey of U.S. Adults. Ann Intern Med. 2020;173: 964-73.

6. Kloc M, Uosef A, Kubiak JZ, Ghobrial RM. Exaptation of Retroviral Syncytin for Development of Syncytialized Placenta, Its Limited Homology to the SARS-CoV-2 Spike Protein and Arguments against Disturbing Narrative in the Context of COVID-19 Vaccination. Biology. 2021; 10: 238.

7. World Health Organization (WHO). Update on COVID19 vaccination in pregnant and lactating women \& 
The New Indian Journal of OBGYN. 2021 (July-December);8(1)

children. [Updated on $2^{\text {nd }}$ June 2021]. Available from: https://cdn.who.int/media/docs/default-source/2021-dhadocs/update-on-who-interim-recommendations-on-c-19vaccination-for-pregnant-and-lactating-women-70.pdf?sfvrsn=2c1d9ac8_1\&download=true

8. International Federation of Gynecology and Obstetrics (FIGO). COVID-19 Vaccination for Pregnant and Breastfeeding Women. [Online] 2021. [Cited: April 28, 2021]. Available from: https://www.figo.org/covid-19vaccination-pregnant-and- breastfeeding women.

9. Society of Obstetricians and Gynaecologists of Canada. SOGC Statement on COVID-19 Vaccination in Pregnancy. [Accessed May 7, 2021]. 2021. Available from: https://sogc.org/ common/uploaded\%20files/ Latest\%20News/SOGC_Statement_COVID-19_ Vaccination_in_Pregnancy.pdf

10. American College of Obstetricians and Gynecologists. Vaccinating pregnant and lactating patients against
COVID-19: practice advisory. December 2020. [Updated on 28 April 2021]. [Accessed on: May 7, 2021]. Available from: https://www.acog.org/clinical/ clinical-guidance/ practice-advisory/articles/2020/12/ vaccinating-pregnant-and-lactating-patients-againstcovid-19.

\section{Anita Yadav ${ }^{1}$, Jyoti Baghel ${ }^{2}$, Avinash Prakash ${ }^{3}$, Rajneesh Rawat ${ }^{4}$}

${ }^{1}$ Associate Professor, Department Of Obstetrics and Gynecology, AIIMS Nagpur, Maharashtra, India;

${ }^{2}$ Senior Resident, Department Of Obstetrics and Gynecology, AIIMS Nagpur Maharashtra, India;

${ }^{3}$ Assistant Professor, Department Of Anesthesiology, AIIMS Nagpur, Maharashtra, India; ${ }^{4}$ Senior Resident, Department of General Surgery, GMC Nagpur, Maharashtra, India. 